to their increased use by walkers and cyclists. The fourth revision of the one-inch maps is making progress in the south of England, and Sheet 144 has been published in the new style. On the other hand, the revision of the six-inch sheets has fallen into arrears, which it is hoped will shortly be overtaken. Owing to lack of adequate staff, it has become necessary to restrict revision of the $1 / 2500$ scale plans to those sheets which are found to be very considerably out of date owing to development of the ground. By this restriction it is hoped to overtake the more important arrears of work in areas of recent urban growth. Key maps of Great Britain attached to the Report show that in the greater part of Scotland and Wales and much of England the last revision of the 1/2500 and six-inch scales was more than twenty years ago.

\section{Manufacture of Electric Railway Equipment}

The surburban services of the Danish State Railway around Copenhagen are to be converted to electric working on the high-pressure direct current system at 1500 volts. We learn from the English Electric Journal for July that the contract for 42 motor coaches and 21 trailer coaches has been awarded to the English Electric Company. There are now 'English Electric' equipments operating railways in seventeen different countries of the world. The Danish State Railway is the fifty-sixth railway to be electrified with the Company's material. The first high-voltage direct current electric railway operating in the world was the Bury-Holcombe Brook route of the Lancashire and Yorkshire Railway. In 1913, the English Electric Company developed the motors and control gear used on this line, which operated on 3600 volts. Few companies have had such worldwide experience in making electric railway equipment of all kinds.

\section{Baltic Geographical Studies}

THE report of the twenty-fourth meeting of German geographers held at Danzig on May 26-28, 1931, has been published as a volume (Verhandlungen und wissenschaftliche Abhandlungen des 24 Deutschen Geographentages, Breslau), which contains, in addition to the proceedings of the conference, a number of valuable papers. These cover a wide range of topics, but perhaps the most striking is a series on Baltic geography, including a paper by Prof. G. Braun on the oscillations of level of north-western Europe and the development of the Baltic from glacial times. A tabulated chronology of changes in the area makes an interesting study. Prof. B. Schulz writes on the waters of the Baltic, and Dr. W. Quade contributes a long study on the evolution of the port of Danzig in relation to the changes in the mouths of the Vistula. This paper is illustrated by a number of old charts.

\section{The Imperial Economic Committee}

THE twenty-sixth Report of the Imperial Economic Committee consists of a review of its constitution and work, and traces the development of its terms of reference. Suggested at the Imperial Economic Conference of 1923, the Committee was brought into being in 1925 with very restricted terms of reference that dealt only with the marketing of Empire food products in Great Britain. This led to the institution of the Empire Marketing Board in 1926, the year in which the Imperial Conference widened the work of the Committee to include the consideration of raw materials of manufacture as well as foodstuffs, and also industries and trades. The Conference of 1930 laid stress on the survey of mineral resources, and entrusted the Committee with the study of various aspects of Imperial co-operation. Its numerous reports on various products and materials are of considerable scientific value.

\section{Announcements}

THE opening meeting of the eighth session of the Electroplaters' and Depositors' Technical Society will be held on Sept. 28, at Lyons' Angel Café, Islington, N.1, when a discussion will be held on "The Possibilities of Standardising Electrodeposits".

THe Institute of Transport has made the following premium awards for the session 1931-32: Institute Triennial Gold Medal to Sir Lynden Macassey ; Railway (Operating) Gold Medal to H. H. Mauldin; Railway (Engineering) Gold Medal to Sir Harold Hartley; Road Transport (Passenger) Grold Medal to Horace M. Wyatt; Water Transport (Canal) Gold Medal to A. J. Pearson; and Institute Graduate Silver Medal to J. M. Powell.

Ornithologists will be interested in Messrs. Wheldon and Wesley's new catalogue of ornithological works, which includes 2039 items. The collection is notable for the large number of important books it contains, and readers unfamiliar with the demand for such works may be surprised to learn that the seven volumes of Lilford's " Birds of the British Isles" are priced at $£ 32$, Dresser's " History of the Birds of Europe " at $£ 48$, Gould's "Birds of Europe " at $£ 70$, and his "Birds of Asia" at $£ 175$.

THe following scholarships have been awarded by the Institution of Electrical Engineers for 1932: Ferranti scholarship to C. D. J. Statham (University of Sheffield); Duddell scholarship to P. J. Rattue (Staveley Grammar School); Silvanus Thompson scholarship to W. E. Arnold (London Midland and Scottish Railway Co.); Swan memorial scholarship to G. N. Davison (Sunderland Technical College); David Hughes scholarship to R. G. Armstrong (University College, London); Salomons scholarship to J. S. Wright (King's College, London); War Thanksgiving education and research fund (No. 1) to G. $J^{\circ}$. Scoles (University College, London) and T. H. Walker (University of Sheffield); Thorrowgood scholarship to B. O. Banks (Metropolitan Railway).

Members of the staff of the Rothamsted Experimental Station are offering to give, during the forthcoming winter, a few lectures on the experimental work of the Station, to chambers of agriculture and horticulture, farmers' clubs, farm workers' associations, agricultural societies, etc. No fee will be charged for such lectures, but the association engaging the lecturer must defray his expenses. The subjects offered include manures, soil micro-organisms, agricultural botany, agricultural chemistry, soil physics, entomology, and mycology. Further particulars can be obtained from the Secretary, Rothamsted Experimental Station, Harpenden, Herts.

$$
\text { No. 3282, VoL. 130] }
$$

